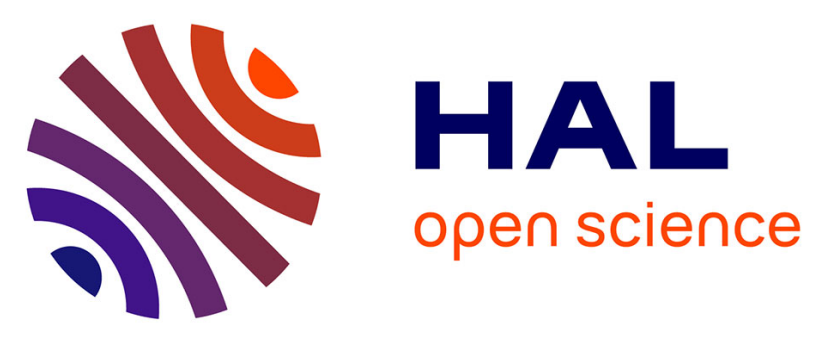

\title{
New Insights into Mesolithic Human Diet in the Mediterranean from Stable Isotope Analysis: The Sites of Campu Stefanu and Torre d'Aquila, Corsica
}

Gwenaëlle Goude, M. Willmes, R. Wood, P. Courtaud, F. Leandri, J. Cesari, Rainer Grün

\section{To cite this version:}

Gwenaëlle Goude, M. Willmes, R. Wood, P. Courtaud, F. Leandri, et al.. New Insights into Mesolithic Human Diet in the Mediterranean from Stable Isotope Analysis: The Sites of Campu Stefanu and Torre d'Aquila, Corsica. International Journal of Osteoarchaeology, 2017, 27 (4), pp.707 - 714. 10.1002/oa.2578 . hal-01649643

\section{HAL Id: hal-01649643 https://hal.science/hal-01649643}

Submitted on 27 Aug 2019

HAL is a multi-disciplinary open access archive for the deposit and dissemination of scientific research documents, whether they are published or not. The documents may come from teaching and research institutions in France or abroad, or from public or private research centers.
L'archive ouverte pluridisciplinaire HAL, est destinée au dépôt et à la diffusion de documents scientifiques de niveau recherche, publiés ou non, émanant des établissements d'enseignement et de recherche français ou étrangers, des laboratoires publics ou privés. 


\section{International Journal of Osteoarchaeology - Short report}

Title:

New insights into Mesolithic human diet in the Mediterranean from stable isotope analysis:

The sites of Campu Stefanu and Torre d'Aquila, Corsica

*Gwenaëlle Goude ${ }^{1}$, Malte Willmes ${ }^{2}$, Rachel Wood ${ }^{3}$, Patrice Courtaud ${ }^{4}$, Franck Leandri ${ }^{5,6}$, Joseph Cesari ${ }^{1}$, Rainer Grün ${ }^{7,3}$

1- Aix Marseille Univ, CNRS, Minist Culture \& Com, LAMPEA, Aix-en-Provence, France

2- Department of Wildlife, Fish, \& Conservation Biology, University of California Davis, CA, USA, malte.willmes@googlemail.com

3- Research School of Earth Sciences, The Australian National University, Bldg. 142 Mills Rd, Canberra 2602, ACT, Australia

4- PACEA UMR 5199, Anthropologie des Populations Passée et Présentes, Université de Bordeaux, 33615, Pessac Cedex, France

5- Ministère de la Culture et de la Communication, Direction régionale des affaires culturelles de Corse, France

6- UMR 5608 TRACES, CNRS, University Toulouse Jean-Jaurès, 31058 Toulouse Cedex 9, France

7- Research Centre of Human Evolution, Environmental Futures Research Institute, Griffith University, 170 Kessels Road, Nathan, QLD 4111, Australia

This article has been accepted for publication and undergone full peer review but has not been through the copyediting, typesetting, pagination and proofreading process which may lead to differences between this version and the Version of Record. Please cite this article as doi: $10.1002 /$ oa.2578 
*Corresponding author: Aix Marseille Université, CNRS, Ministère de la culture et de la communication, LAMPEA UMR 7269, Maison Méditerranéenne des Sciences de l’Homme, 5 rue du Château de l'Horloge, BP 647, 13094 Aix-en-Provence, France; goude@mmsh.univaix.fr

Running title:

New insights into Mesolithic human diet in Corsica

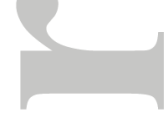

Key words:

Human remains, Carbon isotopes, Nitrogen isotopes, Prehistory

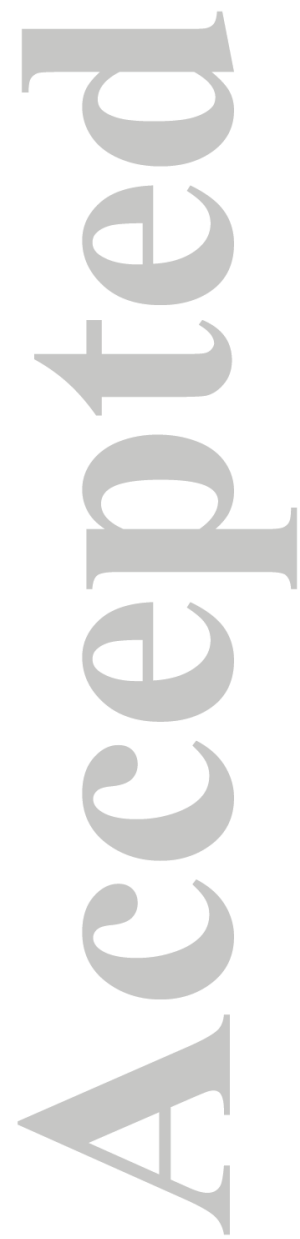




\section{Abstract}

Mesolithic human remains are rare in the archaeological record of the French Mediterranean. Only the island of Corsica has so far produced relatively well preserved burials, and recent archaeological excavations have brought to light new Mesolithic human remains. The site of Cатри Stefanu, located in Sollacaro in the southeast of the island, contained a collective burial of 7-8 individuals in a previously unobserved funerary context. A re-evaluation of collections in regional museums yielded the remains from another Mesolithic individual from the site of Torre d'Aquila, excavated at Pietracorbara, in the northern part of the island, at the beginning of the 1990s. These two discoveries presented the rare opportunity to obtain new radiocarbon dates and paleodietary insights from this crucial time period using stable isotope analysis $\left(\delta^{13} \mathrm{C}, \delta^{15} \mathrm{~N}\right)$ on collagen. From Campu Stefanu one individual had sufficient collagen preserved for radiocarbon dating, revealing that it is the oldest Mesolithic human known on the island, dated to 10216-9920 cal. BP. At Torre d'Aquila, radiocarbon dates indicate that the individual belonged to a younger Mesolithic phase than Campu Stefanu, dated to 9903$9596 \mathrm{cal} . \mathrm{BP} . \delta^{13} \mathrm{C}$ and $\delta^{15} \mathrm{~N}$ isotope ratios are similar between the Campu Stefanu and Torre d'Aquila individuals and indicate a diet dominated by the consumption of terrestrial animal protein, and a lack of marine resources. These findings are in contrast with the previous results from two other Mesolithic individuals from Corsica from the sites of Araguina Sennola and Monte Leone, for which about $25-30 \%$ of the consumed proteins came from a marine diet. The dietary variability recorded in Corsica is consistent with results obtained from Mesolithic human remains of Sicily and the Iberian Peninsula. We can hypothesize, that despite the nomadic lifestyle, the distance to the sea played a major role in Mesolithic food choices in Corsica. 


\section{Introduction}

The first human occupations on the island of Corsica have been documented from archaeological excavations during the 1970 s on seven Mesolithic sites $\left(10^{\text {th }}-9^{\text {th }}\right.$ millennium BP; Costa et al. 2003). Most of these sites are located close to the present day coast line and show a local exploitation of both raw material and food resources (Costa et al. 2003; Vigne, 2004). Corsican pika (Prolagus sardus), a small terrestrial herbivore, dominates the faunal assemblages, sometimes up to $80 \%$. Other small rodents, birds, shellfish and fish make up the rest of the animal remains. Despite the proximity to the sea, marine resources are often scarce at ca. 20\% (Vigne, 1995). Zooarchaeological analyses show seasonality in food resources acquisition, with fish and bird preferentially caught during spring and summer, and Corsican pika during the end of summer and autumn (Vigne, 2004).

Until 2007, Mesolithic human remains were found and studied at three sites: Monte Leone, and l'Araguina Sennola, in the southern part of the island near Bonifacio, and Torre d'Aquila in northern part of the island near Pietracorbara (Figure 1). At Monte Leone (ML), one poorly preserved female individual, two immature individuals and a few dental remains were described (David, 1999). Radiocarbon dating was performed on bones of Corsican pika, resulting in age estimates of 9533-9290 cal. BP (AA-18112), and 9126-8663 cal. BP (AA18108) (Vigne, 1997). At Araguina Sennola (AS), a well preserved skeleton of a female was studied by H. Duday (1975). This individual showed specific pathological traits indicating that she was handicapped long before her death (Duday, 1975). Finally, at Torre d'Aquila (TA), remains from a female were found in a Mesolithic layer (Magdeleine 1995; Bouville 1995), but no radiocarbon date was obtained.

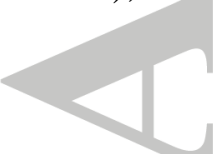

At the end of the 1990s, stable isotope ratios $\left(\delta^{13} \mathrm{C}, \delta^{15} \mathrm{~N}\right)$ were measured for the first time on Prehistoric human remains from Corsica on the two adult women of ML (Pouydebat, 1997) 
and AS (Bocherens, 1999), as well as on animal bones from ML (Corsican pika, grouper Serranidae, European pilchard - Sardina pilchardus, sea bream - Sparus sp., seal - Phocidae, and dolphin - Tursiops sp.; Pouydebat, 1997). Isotopic results obtained on AS and ML are consistent with zooarchaeological data of these sites, indicating a protein intake based on terrestrial game (Corsican pika) and a consumption of marine food, possibly up to $30 \%$ (Pouydebat, 1997; Costa et al. 2003; Vigne, 2004). Archaeological studies demonstrated that the settlements were temporary occupied by small nomadic human groups, described as "trapper-fisher", as their subsistence activities were mainly based on animal trapping and fishing (Costa et al. 2003).

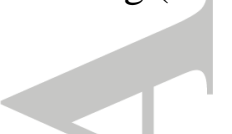

In 2007, new archaeological discoveries in Corsica revealed additional Mesolithic human remains at the site of Cатрu Stefanu (CS) located near Sollacaro (Figure 1), at ca. $7 \mathrm{~km}$ from the current western coastline. Considering relative sea level change (ca. -50m; Lambeck and Bard, 2000) and bathymetric data (Pluquet, 2006), the site was not significantly further away from the shoreline during the occupation period. Excavated from 2007 to 2011, CS delivered remains of several occupations ranging from the Mesolithic to Iron Age. Among various structures (Cesari et al. 2008; 2011), a natural rockshelter included a burial with 7-8 individuals (Courtaud et al. 2014). At the bottom of the rockshelter a partially preserved human skeleton was discovered, covered by many bones of other partial individuals, including anatomical connections and scattered bones. This funerary assemblage is unknown for this period and region. In addition, no typical Mesolithic elements like seashells, or flints, were associated with the funeral deposit. Only some ochre covered the cranium of the most complete individual. Two radiocarbon dates on bone collagen from a humerus bone of the first body (CS1) deposited in the burial (lower level of the stratigraphy, layer 4 R32), revealed that it is the oldest individual found in Corsica identified so far (10216-9920 cal. BP, 
Courtaud et al. 2014). Considering the importance of this discovery, a re-evaluation of Mesolithic human remains in Corsica was attempted and new radiocarbon dating was performed in 2014 on two human remains of TA (TA1; right M1 and right radius; rockshelter $\mathrm{n}^{\circ}$ 2, layer 9) at the Australian National University radiocarbon laboratory (Fallon et al. 2010). Age estimates indicate that the female of TA (TA1) belongs to a younger phase of the Mesolithic (9903-9596 cal. BP) compared to CS1, but is older than AS and ML (Table 1).

Considering the scarcity of Mesolithic human remains in the French Mediterranean and the palaeodietary data already obtained from two Mesolithic women in the south of the island, we performed new stable isotope analysis on the human remains of CS1 and TA1. These new data aim at documenting hunter-gatherer behaviours in different environmental contexts (coastal vs. inland) and aim to add to our understanding of the different environmental exploitations in coastal areas from the Western and Central Mediterranean.

\section{Stable isotope analysis}

Carbon and nitrogen stable isotope ratios measured on bone collagen are efficient proxies to evaluate (1) the contribution of animal protein intake and (2) the environmental origin of the consumed resources. At the base of the food chain, plants have specific $\delta^{13} \mathrm{C}$ and $\delta^{15} \mathrm{~N}$ ratios according to climatic and edaphic conditions, photosynthetic pathways and species (e.g. Mariotti 1982; Virginia and Delwiche 1982; Farquhar et al. 1989). Plant consumers take up the specific $\delta^{13} \mathrm{C}$ and $\delta^{15} \mathrm{~N}$ ratios from the plants and this isotope ratio is incorporated into bone collagen with isotopic fractionation (e.g. Schoeller, 1999). This isotopic fractionation is considered as ca $0-1 \%$ for $\mathrm{C}$ and 3 to $5 \%$ for $\mathrm{N}$ between prey-predator bone collagen (e.g. Bocherens and Drucker 2003). $\delta^{13} \mathrm{C}$ and $\delta^{15} \mathrm{~N}$ stable isotope ratios are efficient environmental markers and are commonly used for differentiating marine vs. terrestrial environments 
(Schoeninger and De Niro 1983) and for evaluating the relative quantity of ingested animal protein, provided that the range of values defining the local environment based on animal and/or botanical isotopic data is known (e.g. Goude and Fontugne, 2016). In human populations, an exclusively marine diet leads to a bone collagen $\delta^{13} \mathrm{C}$ of about $-13 \%$ and an exclusively terrestrial $\mathrm{C}_{3}$ diet to a bone collagen $\delta^{13} \mathrm{C}$ of about $-20 \%$ or less (e.g. Chisholm et $a l ., 1982)$. Animals whose diet consisted entirely of marine resources have a $\delta^{15} \mathrm{~N}$ on average of $9 \%$ higher $(14.8 \pm 2.5 \%)$ than those with an entirely terrestrial diet $(5.9 \pm 2.2 \%$, while those with a mixed diet have intermediate values according to the environment (Schoeninger et al. 1983). More, in depth methodological information can be found in Bocherens and Drucker (2005), Lee-Thorp (2008), Balasse et al. (2015), and Makarewicz and Sealy (2015). Due to the ongoing remodelling of bone, $\delta^{13} \mathrm{C}$ and $\delta^{15} \mathrm{~N}$ stable isotope ratios of collagen provide information on the last years of life. The remodelling is faster during infancy and slows down with the passing years (Valentin 2003). In the case of adult individuals, as at TA1 and CS1, stable isotope data reflect an average of food consumed during the last 15 years before death (Hedges et al. 2007).

The adult of TA and four individuals buried at CS were sampled (long bone, cortical material), but for CS, only one individual (CS1) had sufficient collagen preserved to be analysed. This is the same individual as aged by radiocarbon dating. Preparation of the archaeological material was performed at the biochemical laboratory of LAMPEA using standard protocols for bone powder developed by Longin (1971) and Bocherens (1992), details also in Goude (2007). Carbon and nitrogen content and isotopic ratios were obtained from $1 \mathrm{mg}$ of freeze-dried collagen by EA-IRMS (Europa Scientific 20-20 IRMS, with reproducibility below $0.1 \%$; Iso-Analytical Ltd, Crewe, UK). The extracted collagen analysis meets the quality criteria (Table 2; DeNiro 1985; van Klinken 1999). 


\section{Results and discussion}

Results from the individuals from CS1 and TA1 indicate a diet based on terrestrial animal proteins (Table 2). The comparison with animal and the other Corsican human data (Table 3) reveal different subsistence strategies for the Mesolithic period. Individuals on the sea shore show as much as 30\% of marine resources in their diet (Pouydebat, 1997 and Costa et al. 2003), while CS1 and TA1 individuals do not show any significant intake of marine fish/mammals (less than $10 \%$, if at all). The new stable isotope data indicate a dominantly terrestrial diet and support the hypothesis of an exploitation of the nearby environment during the Mesolithic in Corsica. The observed spatially variable dietary patterns raise questions regarding the possible mobility of Mesolithic people.

Only a few excavations in the Mediterranean context have delivered Mesolithic human and animal bones allowing biochemical investigations. Using published data, we compared the Corsican data to other Mesolithic human groups in Sicily, the Iberian Peninsula and the Adriatic coast (ca. 9700-7100 cal. BP; Garcia Guixé et al. 2006; Lightfoot et al. 2011; Mannino et al. 2011; 2012; Fernández-López de Pablo et al. 2013; Salazar-García et al. 2014; Figure 1; Table 3). These sites are relevant for comparison as most of the human groups had access to both marine and terrestrial environments, similar to Corsica. These previous studies have shown a large variability of human $\delta^{13} \mathrm{C}$ and $\delta^{15} \mathrm{~N}$ stable isotope data, indicating individuals with significant marine protein intake, and other individuals utilizing mainly terrestrial resources. In some cases, marine resources consumption can be linked to the ability to gain easy access to the seashore (e.g. El Collado). In other cases, the proximity to the seashore does not appear to influence the dietary habits (e.g. Grotta dell'Addaura). The dietary diversity and the generally small marine resource intake observed in Corsica is thus consistent with the general pattern defined from the Mesolithic human remains in the Mediterranean. When considering only CS1 and TA1 human samples in Corsica, the trophic 
step ( $\Delta^{15} \mathrm{~N}_{\text {human-herbivore, }}$ computed with medians) is quite similar to what is recorded for the other Mediterranean sites (from 3.6 to 5.4\%o for nitrogen and from 1.2 to $1.4 \%$ o for carbon; Figure 2). If we consider AS and ML human samples in Corsica, the trophic step is more similar to some individuals from El Collado, Pupićina cave or Grotta d'Oriente ( $>5 \%$ for $\left.\delta^{15} \mathrm{~N}\right)$. Fish, marine mammals, and molluscs are part of the diet of these individuals, but their contribution to the diet is more modest, than what we can observe in Mesolithic sites of the Atlantic coast, e.g. 44-87\% of marine resources at Téviec and Hoëdic, Brittany’s islands (Schulting and Richards 2001). During the Mesolithic, terrestrial animals seem to have constituted the main food supply in the Mediterranean areas considered in this study, either as deer in Sicily (Mannino et al. 2012), or Corsican pika in Corsica (Vigne, 2004).

Dietary dichotomy observed between Atlantic and Mediterranean Mesolithic coastal settlements could be linked to the availability of nearby food resources, particularly in marine ecosystem, and to environmental parameters, such as tidal amplitudes (Fa, 2008). These results further document the geographical difference of the subsistence shift (or lack thereof) during the Mesolithic-Neolithic transition (e.g. Richards and Schulting, 2003). The poor preservation of bone organic matter in these sites makes it challenging, but our findings indicate that it is worthwhile to attempt new analyses (e.g. $\delta^{34} \mathrm{~S}$, amino acid). Further investigation on Mesolithic diet in a Mediterranean area such as Corsica is essential to understand the role and influence of different ecosystems on resources acquisition with the aim to better interpret the dietary shift occurring with the advance of agriculture and its socioeconomic consequences.

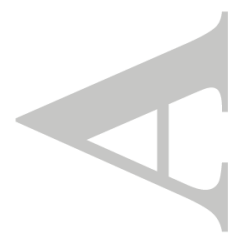




\section{Acknowledgements}

The authors thank SRA-DRAC Corse for sampling authorization and for access to unpublished archaeological documentation and the French Minister of Culture and Communication for funding. Furthermore, we are grateful to E. Pouydebat for her personal communication on the data of Monte Leone and V. Miclon for his laboratory assistance.

Aspects of this study were funded through ARC Discovery Grant 110101415 (Grün et al.)

Understanding the migrations of prehistoric populations through direct dating and isotopic tracking of their mobility patterns.
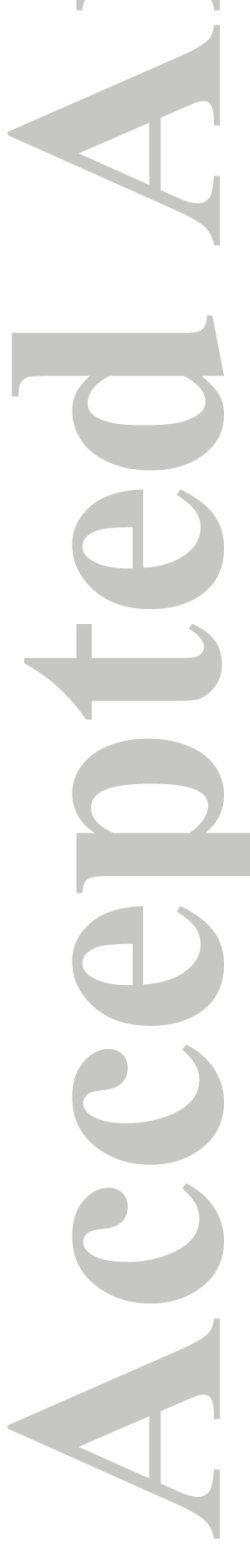


\section{References}

Ambrose SH, and Norr L. 1993. Experimental evidence for the relationship of the carbon isotope ratios of whole diet and dietary protein to those of bone collagen and carbonate. In:

Lambert JB, and Grupe G, editors. Prehistoric human bone Archaeology at the molecular level. Berlin: Springer-Verlag. p 1-37.

Balasse M, Brugal JP, Dauphin Y, Geigl EM, Oberlin C, and Reiche I. 2015. Messages d'os. Archéométrie du squelette animal et humain. Paris: Editions des archives contemporaines.

$530 \mathrm{p}$.

Bocherens H. 1992. Biogéochimie isotopique (13C,15N,18O) et paléontologie des vertébrés : application à l'étude des réseaux trophiques révolus et des paléoenvironnements [Thèse de doctorat]. Paris: Université Paris VI. 317 p.

Bocherens H. 1999. Etude biochimique du squelette prénéolithique de l'abri d'AraguinaSennola (Corse) : résultats préliminaires sur la conservation du collagène et première estimation de la position trophique de l'individu.: S.R.A de Corse. p 5.

Bocherens H., Drucker, D. 2003. Trophic level isotopic enrichment of carbon and nitrogen in bone collagen: case studies from recent and ancient terrestrial ecosystems. International Journal of Osteoarchaeology 13: 46-53.

Bocherens H, and Drucker D. 2005. Biogéochimie isotopique et reconstitution de l'alimentation des Humains anciens et des Hominidés fossiles. In: Dutour O, Hublin J-J, and Vandermeersch B, editors. Objets et Méthodes en Paléoanthropologie. Paris: Comité des Travaux Historiques et Scientifiques. p 343-361.

Bouville CP. 1995. Préhistoire du Cap Corse. Les abris de Torre d'Aquilla Pietracorbara (Haute Corse) : anthropologie. Bulletin de la Société préhistorique française 92(3):378-380. 
Bronk Ramsey C. 1995. Radiocarbon Calibration and Analysis of Stratigraphy: The OxCal Program Radiocarbon 37: 425-430

Bronk Ramsey C. 2001. Development of the Radiocarbon Program OxCal, Radiocarbon, 43: $355-363$

Cesari J, Leandri F, Pêche-Quilichini K, Demouche F, Bressy-Leandri C, and Nebbia P. 2008. Note préliminaire sur l'habitat pré- et protohistorique de Campu Stefanu (Sollacaro, Corsedu-Sud). Actes des 8e RMPR (Marseille, 7-8 novembre 2008). Marseille.

Cesari J, Courtaud P, Leandri F, and Perrin T. 2011. Le site de Campu Stefanu (Sollacaro, Corse-du-Sud) : une occupation du Néolithique ancien et du Mésolithique dans le contexte corso-sarde. Transitions en Méditerranée : ou comment des chasseurs devinrent agriculteurs (Epipaléolithique, Mésolithique, Néolithique ancien) : Colloque international, Toulouse : France (2011). Toulouse.

Chisholm BS, Nelson DE, Schwarcz HP. 1982. Stable isotope ratios as a measure of marine versus terrestrial protein in ancient diet. Science 216:1131-1132.

Costa J-L, Vigne J-D, Bocherens H, Desseberset N, Heinz C, de Lanfranchi F, Magdeleine J, Ruas M-P, Thiébault S, and Tozzi C. 2003. Early settlement on Thyrrhenien islands (8th millennium cl BC): Mesolithic adaptation to local resources in Corsica and Northern Sardinia. In: Krindgen H, Knutson K, Larsson L, Loeffler D, and Akerlund A, editors. Mesolithic on the move, Colloque international UISPP: 6th conference on the Mesolithic in Europe, Stockholm 2000. Oxford: Oxbow Monographs. p 3-10.

Courtaud P., Cesari J., Leandri F., Nebbia P., Perrin T., Petersen H.C., Zemour A. (2014): La sépulture mésolithique de Campu Stefanu (Sollacaro, Corse-du-sud, F), in Chronologie de la Préhistoire récente dans lke sud de la France, 10e Actes des Rencontres Méridionales de 
Préhistoire Récente, Sénépart I., Léandri F., Cauliez J., Perrin T., Thiraut E. (Eds), Octobre 2012, Ajaccio, p. 475-487.

David H. 1999. Etude des peuplements pré-et protohistoriques de Corse. Approche paléoanthropologique [Thèse de Doctorat]. Talence: Université Bordeaux 1. 245 p.

DeNiro MJ. 1985. Post-mortem preservation and alteration of in vivo bone collagen isotope ratios on relation to palaeodietary reconstruction. Nature 317(6032): 806-809.

Duday H. 1975. Le Squelette du sujet féminin de la sépulture prénéolithique de Bonifacio (Corse): étude anthropologique. Essai d'interprétation palethnographique [Thèse de Médecine / Mémoire du Laboratoire d'Anatomie; 24]. Paris: Laboratoire d'Anatomie - Faculté de Médecine. 258 p.

Fa D.A. 2008. Effects of tidal amplitude on intertidal resource availability and dispersal pressure in prehistoric human coastal populations: the Mediterranean-Atlantic transition. Quaternary Science Reviews 27(23-24):2194-2209.

Fallon S.J., Fifield L.K., Chappell J.M. 2010. The next chapter in radiocarbon dating at the Australian National University: Status report on the single stage AMS, Nuclear.

Farquhar G.D., Ehleringer J.R., Hubick K.T. 1989. Carbon isotope discrimination and photosynthesis. Annual Review of Plant Physiology and Plant Molecular Biology 40: 503537.

Fernández-López de Pablo J, Salazar-García DC, Subirà-Galdacano ME, Roca de Togores C, Gómez-Puche M, Richards MP, and Esquembre-Bebiá MA. 2013. Late Mesolithic burials at Casa Corona (Villena, Spain): direct radiocarbon and palaeodietary evidence of the last forager populations in Eastern Iberia. Journal of Archaeological Science 40(1):671-680. 
Garcia Guixé E, Richards MP, and Subirà ME. 2006. Palaeodiets of humans and fauna at the spanish mesolithic site of El Collado. Current anthropology 47(3):549-556.

Goude G. 2007. Etude des modes de subsistance de populations néolithiques (VIe-IVe millénaires av. J.-C.) dans le nord-ouest de la Méditerranée. Approche par l'utilisation des isotopes stables $(\delta 13 \mathrm{C}$ et $\delta 15 \mathrm{~N})$ du collagène [Thèse de doctorat]. Talence-Leipzig: Université Bordeaux 1-Université de Leipzig. 415 p.

Goude G., Fontugne M. 2016. Carbon and nitrogen isotopic variability in bone collagen during the Neolithic period: Influence of environmental factors and diet. Journal of Archaeological Science 70: 117-131.

Hedges REM, Clement JG, Thomas CDL, and O'Connell TC. 2007. Collagen turnover in the adult femoral mid-shaft: Modeled from anthropogenic radiocarbon tracer measurements. American Journal of Physical Anthropology 133(2):808-816.

van Klinken GJ. 1999. Bone collagen quality indicators for palaeodietary and radiocarbon measurements. Journal of Archaeological Science 26: 687-695.

Lanfranchi (de) F. 1973. Le peuplement des hauts bassins du Rizzanese et de l'Ortolo des origines à l'arrivée des Romains. Travaux de l'Institut d'Art préhistorique 15: 213-257.

Lambeck K, and Bard E. 2000. Sea-level change along the French Mediterranean coast for the past 30000 years. Earth and Planetary Science Letters 175:203-222.

Lee-Thorp J. 2008. On isotopes and old bones. Archaeometry 50(6):925-950.

Lightfoot E, Boneva B, Miracle PT, Šlaus M, and O'Connell TC. 2011. Exploring the Mesolithic and Neolithic transition in Croatia through isotopic investigations. Antiquity $85(327): 73-86$ 
Longin R. 1971. New method of collagen extraction for radiocarbon dating. Nature 230:241242.

Magdeleine J. 1995. Préhistoire du Cap Corse: Les abris de Torre d'Aquilla Pietracorbara (Haute Corse). Bulletin de la Société préhistorique française 92(3):363-377.

Makarewicz CA and Sealy J. 2015. Dietary reconstruction, mobility, and the analysis of ancient skeletal tissues: Expanding the prospects of stable isotope research in archaeology. Journal of Archaeological Science 56: 146-158.

Mannino MA, Di Salvo R, Schimmenti V, Di Patti C, Incarbona A, Sineo L, and Richards MP. 2011a. Upper Palaeolithic hunter-gatherer subsistence in Mediterranean coastal environments: an isotopic study of the diets of the earliest directly-dated humans from Sicily. Journal of Archaeological Science 38(11):3094-3100.

Mannino MA, Thomas KD, Leng MJ, Di Salvo R, and Richards MP. 2011b. Stuck to the shore? Investigating prehistoric hunter-gatherer subsistence, mobility and territoriality in a Mediterranean coastal landscape through isotope analyses on marine mollusc shell carbonates and human bone collagen. Quaternary International 244(1):88-104.

Mannino MA, Catalano G, Talamo S, Mannino G, Di Salvo R, Schimmenti V, Lalueza-Fox C, Messina A, Petruso D, Caramelli D et al., 2012. Origin and Diet of the Prehistoric HunterGatherers on the Mediterranean Island of Favignana (Ègadi Islands, Sicily) PloS ONE 7(11).

Mariotti A. 1982. Apport de la géochimie isotopique à la connaissance du cycle de l'azote. PhD Thesis. Université Paris VI, Paris. 476 pp.

Phillips DL, and Gregg JW. 2003. Source partitioning using stable isotopes: coping with too many sources. Oecologia 136:261-269. 
Pluquet F. 2006. Evolution récente et sédimentation des plates-formes continentales de la Corse [PhD]. Corte: Université de Corse. 300 p.

Pouydebat E. 1997. Approche biogéochimique de l'alimentation humaine dans le site prénéolithique du Monte Leone (VIIIe millénaire av J.-C; Bonifacio Corse-du-Sud)

[Mémoire de Maîtrise d'Archéologie]: Université Paris I. 84 p.

Reimer, P.J., Bard E., Bayliss A., Warren Beck J., Blackwell P.G., Bronk Ramsey C., Pieter

Grootes M., Guilderson T.P., Haflidason H., Hajdas I., Hatté C., Heaton T.J., Hoffmann D.L., Hogg A.G., Hughen K.A., Kaiser K.F., Kromer B., Manning S.W., Niu M., Reimer R.W., Richards D.A., Scott E.M., Southon J.R., Staff R.A., Turney C.S.M., van der Plicht J., 2013. IntCal13 and Marine13 Radiocarbon Age Calibration Curves 0-50,000 Years cal BP. Radiocarbon55(4):1869-1887. http://calib.qub.ac.uk/calib/ for on-line calibration program.

Richards MP, and Schulting RJ. 2003. Sharp shift in diet at onset of Neolithic. Nature $425: 366$

Salazar-García DC, Aura JE, Olària CR, Talamo S, Morales JV, and Richards MP. 2014. Isotope evidence for the use of marine resources in the Eastern Iberian Mesolithic. Journal of Archaeological Science 42(0):231-240.

Schoeller DA. 1999. Isotope fractionation: why aren't we what we eat? Journal of Archaeological Science 26: 667-673.

Schoeninger MJ, De Niro MJ, Tauber H. 1983. Stable Nitrogen isotope ratios of bone collagen reflect marine and terrestrial components of prehistoric human diet. Science 220:1381-1383. 
Schulting R. and Richards MP. 2001. Dating women and becoming farmers: new palaeodietary and A.M.S. dating evidence from the Breton Mesolithic cemeteries of Téviec and Hoëdic. Journal of Anthropological Archaeology 20: 314-344.

Valentin J. 2003. Basic Anatomical and Physiological Data for Use in Radiological Protection: Reference Values. ICRP Publication 89: Pergamon. Elsevier. 280 p.

Vigne J-D. 1995. Préhistoire du Cap Corse. Les abris de Torre d'Aquilla Pietracorbara (Haute Corse) : la faune. Bulletin de la Société préhistorique française 92(3):381-389.

Vigne J-D., 1997. L'exploitation des ressources animales au Prénéolithique, in L'aventure humaine préhistorique en Corse, Lanfranchi (de) F., Weiss M.C. (eds.), Albiana, Ajaccio, p. 65-66.

Vigne J-D. avec la collaboration de Balasse M. 2004. Accumulation de lagomorphes et de rongeurs dans le sites mésolithiques corso-sardes: origines taphonomiques implications anthropologiques. In: Brugal JP, and Desse J, editors. Petits animaux et sociétés humaines : du complément alimentaire aux ressources utilitaires : XXIVe rencontres internationales d'archéologie et d'histoire d'Antibes. Antibes: A.P.D.C.A. p 261-281.

Virginia R.A., Delwiche C.C. 1982. Natural 15N abundance of presumed N2 fixing and non N2 fixing plants from selected ecosystems. Oecologia 57: 317-325.

Wood R.E., Arrizabalaga Valbuena A., Camps M., Fallon S., Iriarte-Chiapusso M.J., Jones R., Maroto J., de la Rasilla M., Santamaría D., Soler J., Soler N., Villaluenga A., Higham T.F.G. 2014. The chronology of the earliest Upper Palaeolithic in northern Iberia: New insights from L'Arbreda, Labeko Koba and La Viña. Journal of Human Evolution 69: 91-109. 
Table 1a. AMS radiocarbon dates from Mesolithic sites in Corsica. Calibration was carried out in OxCal v4.2 (Bronk Ramsey, 1995, 2001) against IntCal13 (Reimer et al., 2013). All radiocarbon dates of bone are on collagen. Collagen from S-ANU was purified using an ultrafiltration protocol (as described in Wood et al. 2014).

\begin{tabular}{|c|c|c|c|c|c|}
\hline $\begin{array}{l}\text { Laboratory } \\
\text { number }\end{array}$ & Context & Sample material & ${ }^{14} \mathrm{C}$ date $(\mathrm{BP})$ & $\begin{array}{l}\text { Calibrated }{ }^{14} \mathrm{C} \\
\text { date (cal. } \mathrm{BP} \text {, } \\
95.4 \% \text { range) }\end{array}$ & Reference \\
\hline \multicolumn{6}{|c|}{ Campu Stefanu (CS) } \\
\hline $\begin{array}{l}\text { Beta } 318791 \\
\text { Poz } 44201\end{array}$ & $\begin{array}{l}\text { Individual CS1, } \\
\text { layer } 4 \text { R32 }\end{array}$ & Human humerus & $\begin{array}{l}8940 \pm 40 \\
8970 \pm 60\end{array}$ & $10216-9920$ & $\begin{array}{l}\text { Courtaud et al. } \\
2014\end{array}$ \\
\hline \multicolumn{6}{|c|}{ Torre d'Aquila (TA) } \\
\hline $\begin{array}{l}\text { S-ANU } 38010 \\
\text { S-ANU } 38011\end{array}$ & $\begin{array}{l}\text { Individual TA1, } \\
\text { rockshelter } n^{\circ} 2 \text {, } \\
\text { layer } 9\end{array}$ & $\begin{array}{l}\text { Human } 1^{\text {st }} \text { molar } \\
\text { Human right } \\
\text { distal radius }\end{array}$ & $\begin{array}{l}8790 \pm 50 \\
8715 \pm 50\end{array}$ & 9903-9596 & This study \\
\hline \multicolumn{6}{|c|}{ Araguina Sennola } \\
\hline GIF & layer XVIIIa & Charcoal & $8520 \pm 150$ & $9891-9150$ & $\begin{array}{l}\text { de Lanfranchi, } \\
1973\end{array}$ \\
\hline \multicolumn{6}{|l|}{ Monte Leone } \\
\hline AA 18112 & layers 5 to $2 \mathrm{a}$ & $\begin{array}{l}\text { Prolagus sardus } \\
\text { bone }\end{array}$ & $8415 \pm 65$ & $9533-9290$ & \multirow[t]{2}{*}{$\begin{array}{l}\text { Vigne, 1997, } \\
\text { Costa et al. } 2003\end{array}$} \\
\hline AA 18108 & layers 5 to $2 \mathrm{a}$ & $\begin{array}{l}\text { Prolagus sardus } \\
\text { bone }\end{array}$ & $8050 \pm 60$ & $9126-8663$ & \\
\hline
\end{tabular}


Table 1b. Quality assurance data for bone collagen extracted for radiocarbon dating.

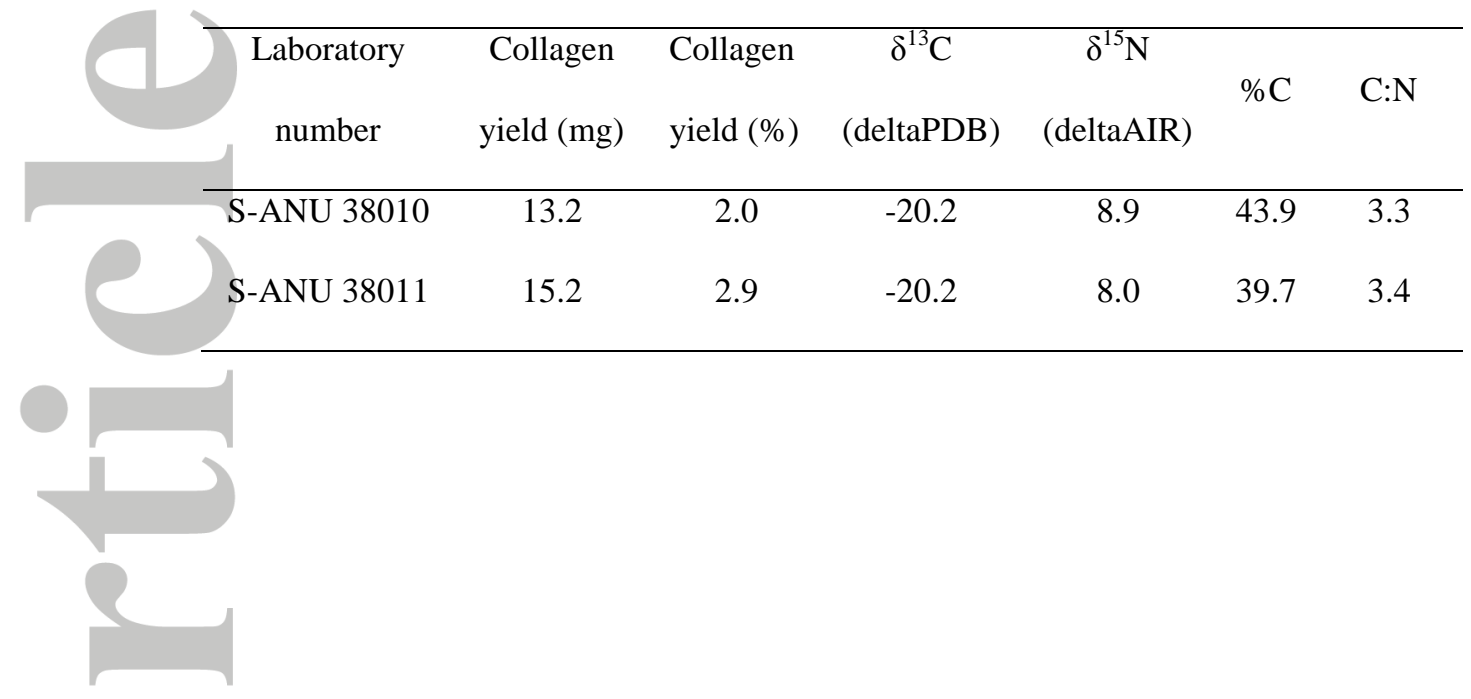

Table 2. Stable isotope ratios and collagen quality criteria of Corsican human bone collagen analysed in this study for palaeodiet.

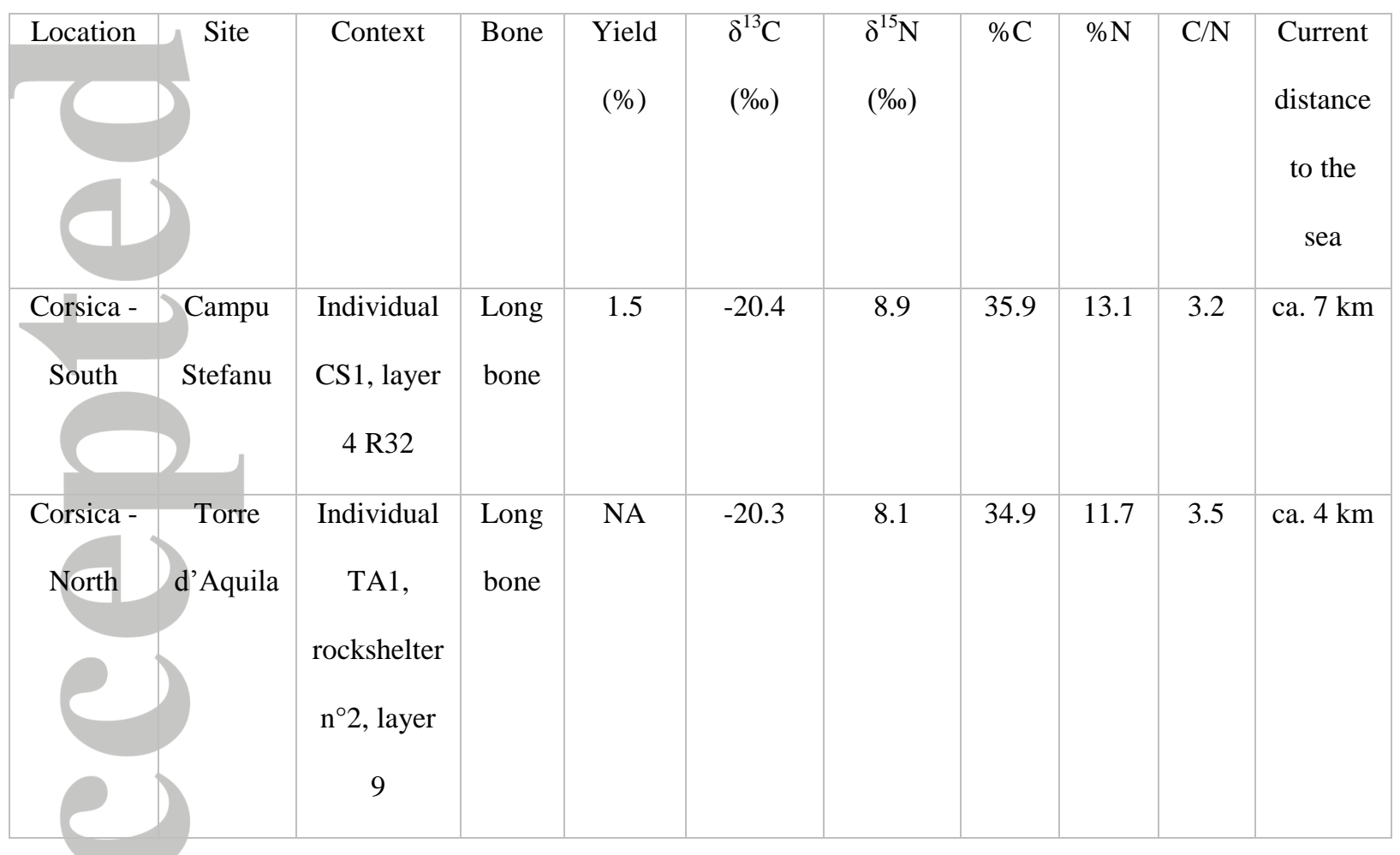


Table 3. Published stable isotope ratios of Corsican Mesolithic humans, as well as Mesolithic herbivores and humans from other Mediterranean/Adriatic sites.

\begin{tabular}{|c|c|c|c|c|c|c|}
\hline Location & Site & Species (N) & $\begin{array}{c}\delta^{13} \mathrm{C}(\% \mathrm{o}) \\
\text { median }\end{array}$ & $\begin{array}{c}\delta^{15} \mathrm{~N}(\% 0) \\
\text { median }\end{array}$ & $\begin{array}{c}\text { Current } \\
\text { distance to the } \\
\text { sea }\end{array}$ & Reference \\
\hline $\begin{array}{r}\text { Corsica } \\
\text { South }\end{array}$ & $\begin{array}{l}\text { Araguina } \\
\text { Sennola }\end{array}$ & Human (1) & -18.8 & 10.6 & seashore & Bocherens 1999 \\
\hline $\begin{array}{r}\text { Corsica } \\
\text { South }\end{array}$ & $\begin{array}{l}\text { Monte } \\
\text { Leone }\end{array}$ & Human (1) & -18.0 & 9.9 & seashore & Pouydebat 1997 \\
\hline $\begin{array}{l}\text { Corsica - } \\
\text { South }\end{array}$ & $\begin{array}{l}\text { Monte } \\
\text { Leone }\end{array}$ & $\begin{array}{l}\text { Prolagus } \\
\text { sardus }(5)\end{array}$ & -21.6 & 4.1 & seashore & Pouydebat 1997 \\
\hline $\begin{array}{c}\text { Iberian } \\
\text { Peninsula- }\end{array}$ & $\begin{array}{l}\text { El Collado, } \\
\text { C. Corona, } \\
\text { C. Santa } \\
\text { Maira, P. } \\
\text { Comptador, } \\
\text { C. Mas Nou }\end{array}$ & Human (22) & -18.5 & 9.2 & $\begin{array}{l}\text { From ca. } 3 \text { to } \\
\qquad 46 \mathrm{~km}\end{array}$ & $\begin{array}{l}\text { Garcia-Guixé et al. } \\
\text { 2006; Fernández- } \\
\text { López de Pablo et al. } \\
\text { 2013; Salazar-Garcia } \\
\text { et al. } 2014\end{array}$ \\
\hline $\begin{array}{r}\text { Ibe } \\
\text { Penir }\end{array}$ & $\begin{array}{c}\text { C. Santa } \\
\text { Maira, P. } \\
\text { Comptador, } \\
\text { C. Mas Nou }\end{array}$ & $\begin{array}{c}\text { Herbivores } \\
\text { (19) }\end{array}$ & -19.8 & 3.8 & $\begin{array}{l}\text { From ca. } 3 \text { to } \\
46 \mathrm{~km}\end{array}$ & $\begin{array}{c}\text { Salazar-Garcia et al. } \\
2014\end{array}$ \\
\hline $\begin{array}{l}\text { Sicilian } \\
\text { island }\end{array}$ & $\begin{array}{l}\text { G. Oriente, } \\
\text { G. Addaura, } \\
\text { G. Molara, } \\
\text { G. Uzzo }\end{array}$ & Human (11) & -19.5 & 10.4 & Less than $2 \mathrm{~km}$ & $\begin{array}{l}\text { Francalacci, 1988; } \\
\text { Mannino et al. 2011; } \\
2012\end{array}$ \\
\hline $\begin{array}{l}\text { Sicilian } \\
\text { island }\end{array}$ & $\begin{array}{l}\text { G. Oriente, } \\
\text { G. Addaura, } \\
\text { G. Molara }\end{array}$ & $\begin{array}{c}\text { Herbivores } \\
\text { (15) }\end{array}$ & -20.9 & 6.4 & Less than $2 \mathrm{~km}$ & $\begin{array}{l}\text { Mannino et al. 2011; } \\
2012\end{array}$ \\
\hline $\begin{array}{l}\text { Adriatic } \\
\text { coast }\end{array}$ & $\begin{array}{l}\text { Vela Spilja- } \\
\text { Vela Luka, } \\
\text { Pupicina }\end{array}$ & Human (4) & -19.2 & 9.7 & $\begin{array}{l}\text { From seashore } \\
\text { to ca. } 7 \mathrm{~km}\end{array}$ & Lightfoot et al. 2011 \\
\hline $\begin{array}{l}\text { Adriatic } \\
\text { coast }\end{array}$ & $\begin{array}{l}\text { Vela Spilja- } \\
\text { Vela Luka }\end{array}$ & $\begin{array}{c}\text { Herbivores } \\
\text { (8) }\end{array}$ & -20.4 & 6.1 & $\begin{array}{c}\text { From seashore } \\
\text { to ca. } 7 \mathrm{~km}\end{array}$ & Lightfoot et al. 2011 \\
\hline
\end{tabular}




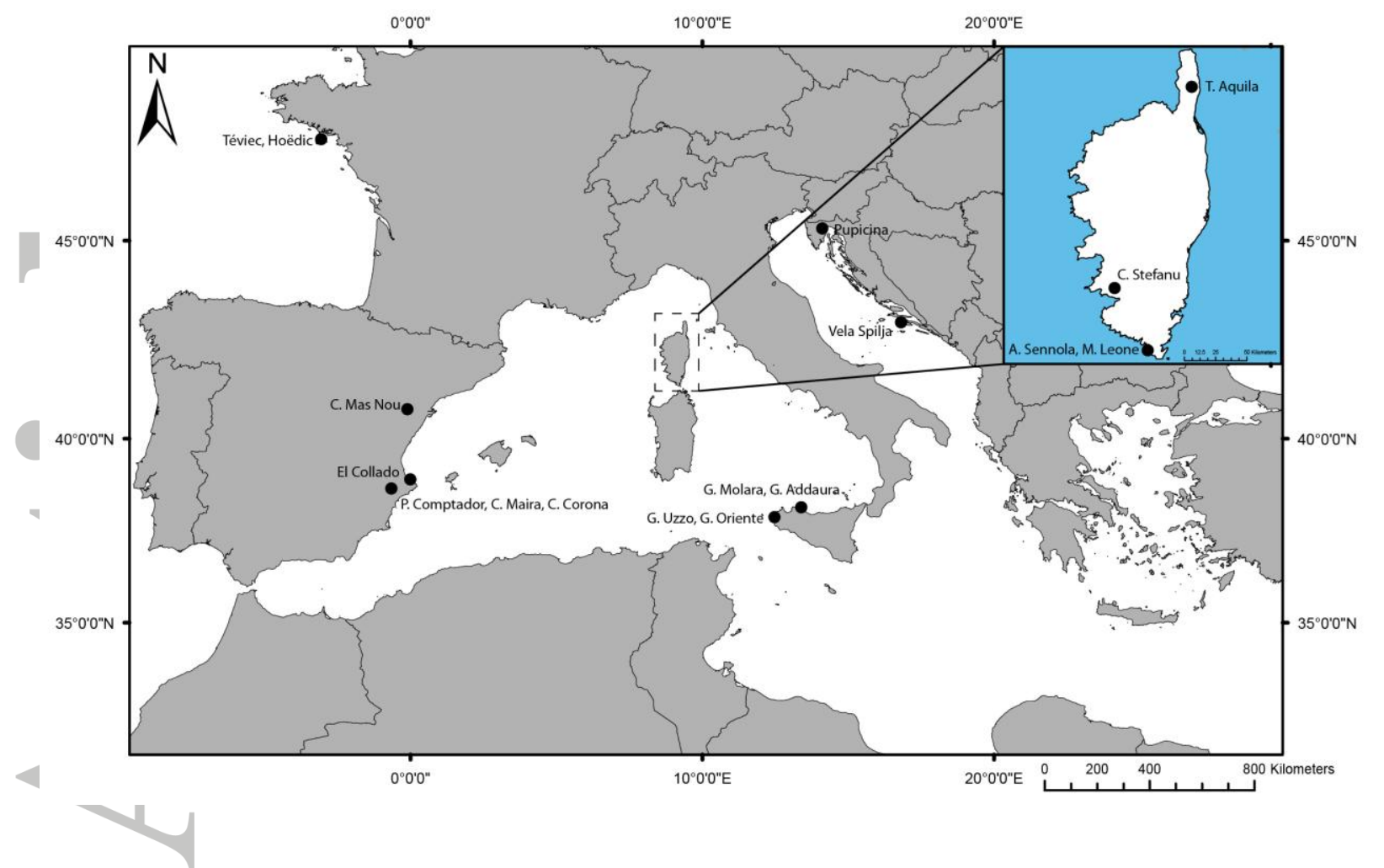

Figure 1. Location of the Mesolithic sites with human stable isotope data in Mediterranean and Adriatic coast. 


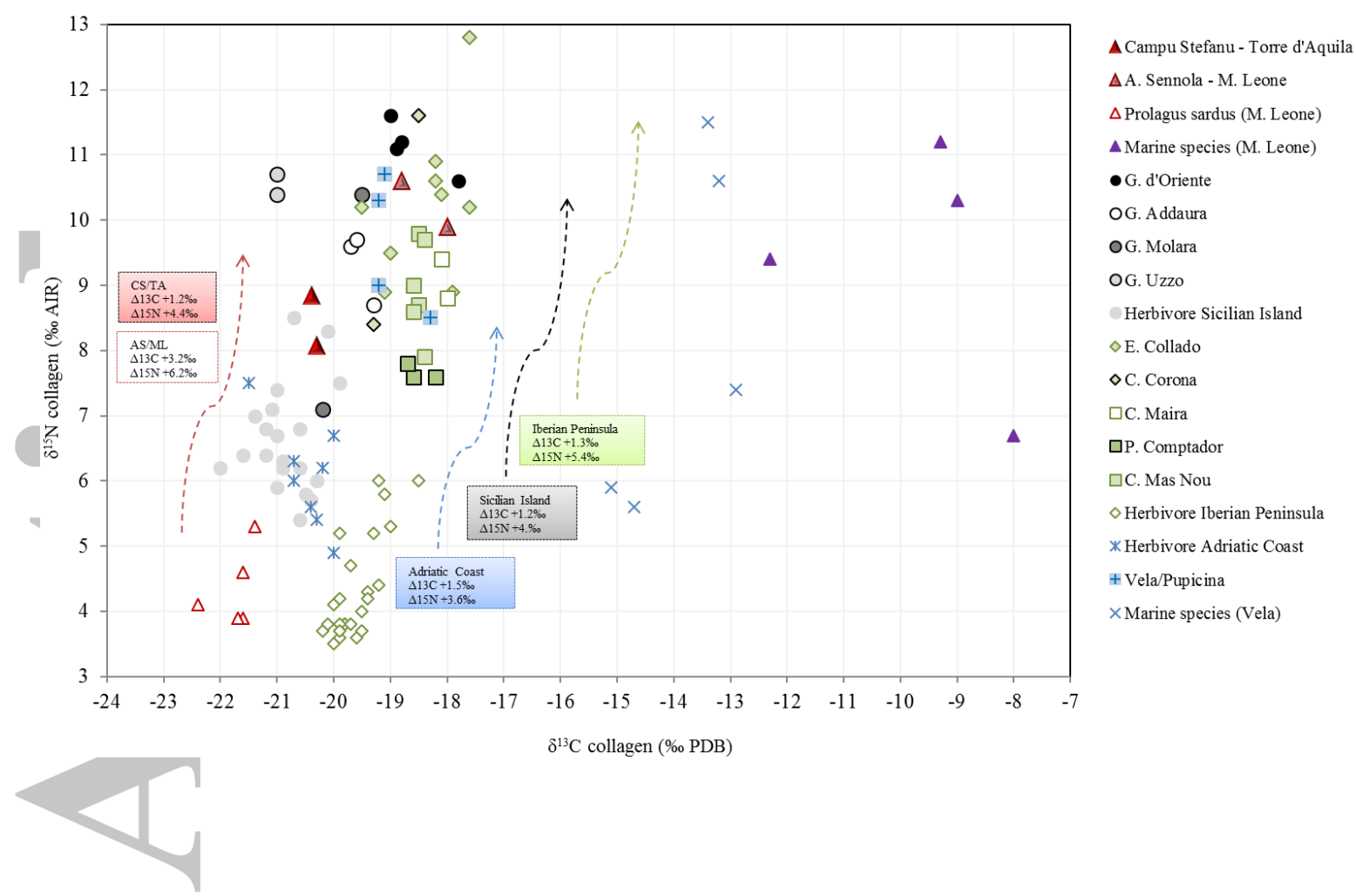

Figure 2. $\delta^{13} \mathrm{C}$ and $\delta^{15} \mathrm{~N}$ stable isotope distribution for Mesolithic remains located on coastal environments. Corsica: this study, Pouydebat, 1997; Bocherens, 1999; Sicily: Mannino et al. 2011, 2012; Croatia: Lightfoot et al. 2011; Spain: Garcia-Guixé et al. 2006; Fernández-López de Pablo et al. 2013; Salazar-Garcia et al. 2014. For human samples, only individuals over 3 years of age were included. Arrows represent the isotopic enrichment (median) between the human group and herbivores of the corresponding area. 